\title{
HET CONTRACT MET BONDJOL VAN JANUARI 1824,
}

\author{
MEDEGEDEELD DOOR
}

E. B. KIELSTRA.

Ter aanvulling van mijn opstel "Sumatra's Westkust van 18191825 " (Bijdragen, 5e volgr. 2e deel bl. 107), ben ik thans in de gelegenheid, het contract mede te deelen hetwelk, den 22n Januari 1824, met de hoofden van Bondjol gesloten werd.

VERBOND VAN VREDE EN VRIENDSCHAP, gesloten tusschen de ondergeteekenden Arend Florentinus van den Berg, voor en vanwege het Nederlandsche gouvernement, als zijnde daartoe behoorlijk door den resident van Padang en onderhoorigheden, Antoine Theodore Raaff, afgevaardigd en gemachtigd, en

de hoofden van het land Bondjol of Alahan Pandjang, de Toewankoe's Imam, Itam en Nan Gapok, onder goedkeuring van voorz. resident van Padang en onderhoorigheden en nader onder die van de Hooge Indische Regeering.

Ten eerste verbinden zich voorz. hoofden van het land Bondjol of Alahan Pandjang, onderling en gezamenlijk, voor altoos en eeuwig:

$a$. dat zij en hunne onderhoorigen, in een voortdurenden vrede en vriendschap met het Nederlandsche gouvernement en zijne onderhoorigheden op Sumatra's Westkust, in de binnenlanden van Sumatra zullen blijven leven;

b. dat zij de hoofden der Padries van de VI Kota's of Kota Lawas, van een gedeelte van Agam, de L Kota's, Lintou, in één woord al degenen van het Menangkabausche rijk die nog vijanden van het Nederlandsch gezag en zijne onderhoorigen zijn, zullen verplichten in vrede met dat gezag of zijne onderhoorige districten en bewoners te leven, of de gemeene zaak van Bondjol of Alahan Pan- 
djang aan te kleven; dan wel, indien hunne pogingen daartoe mochten mislukken, dat zij, voornoemde hoofden van Bondjol of Alahan Pandjang, het Nederlandsche gouvernement krachtdadig zullen bijstaan, hetzij in het onderwerpen van zijne hierboven bedoelde vijanden, dan wel in het afweren van hunne vijandelijke aanvallen op het grondgebied van het Nederlandsch gouvernement of zijne onderhoorigheden;

c. dat zij niets onbeproefd zullen laten om, door hunnen invloed, te bewerken dat aan het Nederlandsche gouvernement worde terugbezorgd het geschut, bestaande in drie metalen 6- en twee 3-ponders, hetwelk zich in het bezit der hierboven vermelde, nog vijandige Padrie-hoofden bevindt; waardoor zij, hoofden van Bondjol of Alahan Pandjang, het overtuigendst bewijs van oprechte welgezindheid en vriendschap omtrent het Nederlandsch gouvernement zullen aan den dag leggen;

d. dat zij al het mogelijke van hunne zijde zullen aanwenden om de bewoners van Rau (gelegen ten N. O. van het land van Bondjol of Alahan Pandjang) te Padang of zijne onderhoorigheden, en zulks bij voorkeur van alle andere plaatsen, ten handel te doen af komen;

e. dat zij de Nederlanders en hunne onderhoorigen zullen toelaten, alle artikelen van handel of voeding, die mochten gewenscht worden, vrij en onbelemmerd in hun land te mogen voeren en te koop aanbieden, en dat deze van hen alsdan alle hulp en bescherming zullen genieten;

$f$ : dat zij het Nederlandsche gouvernement behulpzaam zullen zijn in het afweren of tegengaan van den sluikhandel naar eenig van zijne districten, hetzij in de beneden-, of wel in de bovenlanden;

$g$. dat zij alle vluchtelingen, slaven of pandelingen uit de districten of landen, onder het Nederlandsch gezag behoorende, zullen aanhouden en uitleveren aan de naastbijgelegene Nederlandsche autoriteit;

$h$. dat zij hunne benoodigdheid in zout van het Nederlandsch gezag zullen inkoopen, hetwelk voor hen verkrijgbaar zal worden gesteld, zoowel te Padang als op andere strandplaatsen van zijne onderhoorigheden, tegen den prijs van $f$ 150.- de kojang of $f$.de pikol.

Ten andere verbindt zich het Nederlandsche gouvernement voor altoos en eeuwig, zoo voor zich-zelf als voor zijne onderhoorigen gezamenlijk:

$a$. dat zij wederkeeriglijk in een voortdurenden vrede en vriendschap 
met de hoofden van Bondjol of Alahan Pandjang en hunne onderhoorigen zullen blijven leven;

b. dat zij zich nimmer met betrekking tot de godsdienstige beginselen, het bestuur of beheer van de landen van Bondjol of Alahan Pandjang en hunne onderhoorigheden zullen bemoeien of inlaten, doch wel zorgen dat hunne gebruiken en gewoonten overal in de geheele uitgestrektheid van het Nederlandsch gouvernement op Sumatra worden geëerbiedigd;

c. dat zij de bewoners van Bondjol of Alahan Pandjang of zijne onderhoorigheden zullen toelaten, vrij en onbelemmerd, naar Padang of zijne onderhoorigheden op de Westkust van Sumatra ten handel af te komen, om hunne voortbrengselen om te zetten of wel hunne benoodigdheden af te halen;

d. dat zoodanige afkomende handelaren alle mogelijke bescherming en bijstand zullen ondervinden in de geheele uitgestrektheid van het Nederlandsche grondgebied, doch inzonderheid langs de groote wegen van gemeenschap van het strand naar de Menangkabausche districten;

e. dat zij zich nimmer zallen inlaten met de onderlinge geschillen wan de hoofden van Bondjol of Alahan Pandjang of met die hnner anderhoorigen ;

$f$. dat zij zich mede niet zullen inlaten met de hooflen van Bondjol of Alahan Pandjang eenigen bijstand of onderstemning tegen Europeesche anvallen te verleenen, evenmin als het Nederlandsche gouvernement. hunnen bijstand zal vorderen tegen zijne Luropeesche vijanden;

3. dat zij alle vluchtelingen, slaven of andere personen, die de wijk nit de landen van. Bondjol of Alahan Pandjang of hunne onderhoorigheden in de districten van het Nederlandsch grondgebied ter Westkust van Sumatra nemen, op verzoek van de hoofden van Bondjol of Alahan Pandjang zullen trachten op te sporen, aan te houden en nit te leveren;

h. dat het an de hoofden roomoemd zal worden toegestaan, een of meer agenten te Padang te vestigen, door wier bemiddeling hunne belangen zullen kunnen worden voorgedragen, waargenomen of behartigd.

Ln eindelijk verbinden zich het Nederlandsche gonvernement en de hoofden van Bondjol of Alahan Pandjang gezamenlijk:

dat zij wederzijds zullen toelaten dat, wanneer anderzijdsche bewoners overtredingen zouden begaan, deze in de landen, waar de overtredingen geschieden, naar de plaatselijke wetten en gebruiken zullen worden gestraft. 
En ten laatste, dat het vredesverbond, na behoorlijk bevestigd te zijn, op de openlijkste wijze zal worden bekend gemaakt en afgekondigd, door elk der partijen respectievelijk in de geheele uitgestrektheid van haar grondgebied, en dat, tot voortdurende verzekering daarvan, de hoofden van Bondjol of Alahan Pandjang of hunne afgezanten om de twee jaren naar Padang zullen afkomen, tot herhaling dezer verbintenis (als wanneer een klein gouvernements vaartuig te hunner beschikking zal worden gesteld, om daarmede de reis naar Padang te doen), en wijders, bij hunne aankomst, van het Nederlandsche gouvernement een gift zullen genieten van vier honderd daalders, en op de meest gulle wijze worden ontvangen.

Aldus door de ondergeteekenden, in hoofde dezes vermeld, angegaan en overeengekomen en op de plechtigste wijze met hunne handteekeningen bekrachtigd, in tegenwoordigheid van den Hoogepriester van voornoemde hoofden van Bondjol of Alahan Pandjang, Toewankoe Moediek Padang, te Massang Sampej op de Westkust van Sumatra, op heden den twee eu twintigsten Januari, Een duizend acht honderd vier en twintig.

A. F. VAN DEN Berg.

Bovenstaand verbond van vrede en vriendschap, in afwachting der beslissing van de Hooge Regeering over Nederlandsch-Indië, door mij, luitenant-kolonel, resident en militaire commandant van Padang en onderhoorigheden, voorloopig goedgekeurd op den 26n Januari 1824, of naar de Mohammedaansche tijdrekening den $25_{\mathrm{n}}$ dag van de maand Jamadil Auwat van het jaar 1239.

RAAFF. 